\title{
Terguride stimulates locomotor activity at 2 months but not 10 months after 1-methyl-4-phenyl-1,2,3,6-tetrahydropyridine treatment of common marmosets
}

\author{
Klaus W. Lange, Peter-A. Löschmann a, Helmut Wachtel a, Reinhard Horowski a , Peter Jähnig c, \\ Peter Jenner and C. David Marsden ${ }^{b}$ \\ Parkinson's Disease Society Experimental Research Laboratories, Pharmacology (Group, Biomedical Sciences Dirision, King's College, Manresa Road, \\ I.ondon SW3, U.K., "Research Laboratories of Schering AG, D-1000 Berlin 65, F.R.G., "Unicersity Department of Clinical Neurology, Institute of \\ Neurology, The National Ilospital, Queen Square, London WCI, U.K. and' A F B Comstat GmbH Berlin, Furopacenter, D-1000 Berlin 30, F.R.G.
}

Received 27 June 1991, revised MS received 16 October 1991, accepted 17 December 1991

\begin{abstract}
The mixed dopamine (DA) agonist/antagonist terguride acts as a DA antagonist on normosensitive receptors but shows DA agonistic properties at supersensitive DA receptors. Such a compound could offer an alternative to the treatment of Parkinson's disease with indirect or direct DA agonists. The present study compares the actions of terguride, $4-12 \mathrm{mg} / \mathrm{kg}$ i.p., in naive common marmosets with its effects in animals rendered parkinsonian by administration of 1-methyl-4-phenyl-1,2,3,6-tetrahydropyridine (MPTP), 2 months or 10 months previously, in order to test its antiparkinsonian efficacy. Terguride reduced locomotor activity in naive common marmosets, similar to its effects in rodents and in line with the DA antagonistic activity of the compound. In marmosets treated with MPTP 2 months previously and exhibiting pronounced behavioural motor deficits, terguride stimulated locomotor activity, showing DA agonistic properties under these conditions. In contrast, the locomotor activity of animals that had recovered from MPTP treatment 10 months previously was not altered by terguride. It is concluded that terguride has anti-akinetic efficacy in this primate model of Parkinson's disease. In addition, terguride offers a unique opportunity to differentiate, pharmacologically, the extent of dopaminergic recovery from MPTP treatment in this primate species.
\end{abstract}

MPTP (1-methyl-4-phenyl-1,2,3,6-tetrahydropyridinc); Parkinsonism; Terguride;

Dopamine $\mathrm{D}_{2}$ receptors (mixed agonist/antagonist); (Common marmoset)

\section{Introduction}

The current treatment of Parkinson's disease with indirect or direct dopamine (DA) agonists (i.e., L-Dopa, lisuride, pergolide or bromocriptine) is limited by side effects. Whereas some initial adverse reactions such as nausea and vomiting usually disappear due to rapid tolerance, the incidence of others such as fluctuations in motor performance and involuntary movements increases after long-term treatment with L-Dopa (Marsden and Parkes, 1976). Psychosis is another limiting side effect of all dopaminergic therapies, especially in elderly paticnts. A balanced stimulation of DA receptcrs, taking into account the differential status of DA receptor sensitivity in the course of the disease, could lead to a more specific therapcutic effect and reduction of side effects.

Correspondence to: P.-A. Löschmann, Schering AG, Neuropsychopharmacology, Postfach 6503 11, D-1000 Berlin 65, F.R.G. Tel. 49.30.468 2162, fax 49.30 .46916738 .
Mixed DA agonists/antagonists, with terguride being the prototype compound, are promising for such an approach. Terguride, a derivative of the dopaminergic ergoline lisuride, binds with high affinity to rat striatal DA $\mathrm{D}_{2}$ and to a lesser extent to DA $\mathrm{D}_{1}$ binding sites (Valchár ct al., 1987). The compound acts as a DA antagonist in normal rats but shows DA agonistic propertics in reserpine-treated rodents (Wachtel and Dorow, 1983). In naive rats, terguride dose dependently inhibits locomotor activity. However, stimulation occurs after subchronic pretreatment with rescrpine. Similarly, terguride does not induce stereotypies in rats treated acutely with reserpine, but does so after subchronic treatment with reserpine (Wachtel et al., 1984). Furthermore, and in common with classical DA agonists, terguride suppresses hyperprolactinaemia in female rats pretreated with reserpine and induces contralateral rotations in rats injected unilaterally with 6-hydroxydopaminc into the substantia nigra (Dlabăc and Krejčí, 1980; Löschmann et al., 1991a).

Administration of 1-methyl-4-phenyl-1,2,3,6-tetrahydropyridine (MPTP) to man or non-human primates 
(Davis et al., 1979; Langston et al., 1983; Burns et al., 1983) including common marmosets (Jenner et al., 1984) induces a parkinsonian syndrome due to the selective destruction of nigrostriatal neurones, which causes a substantial decrease in the DA content of the caudate nucleus and putamen and a corresponding decrease in $\left[{ }^{3} \mathrm{H}\right]$ DA uptake (Jenner et al., 1984). The deficits in motor performance produced by MPTP treatment of common marmosets respond to classical anti-parkinsonian drugs such as L-Dopa in combination with a peripheral decarboxylase inhibitor (Jenner et al., 1984), or DA receptor agonists such as (+)PHNO (Nomoto et al., 1987), N-0437 (Löschmann et al., 1989) or the ergoline derivative lisuride (Löschmann ct al., 1991b). The MPTP-treated monkey appears to be the most suitable pharnacological model of Parkinson's disease currently available.

Common marmosets recover from the initial symptoms induced by MPTP treatment over a period of several months. This bchavioural recovery is associated with increased DA turnover in the caudate-putamen (Jenner et al., 1984; Rose et al., 1989) and is not reversed by further treatment with MPTP (Ueki et al., 1989). The present study was designed to test the hypothesis that the behavioural recovery in common marmosets after MPTP treatment would be associated with a change in their behavioural response to a mixed DA agonist/antagonist. We therefore compared the actions of terguride in naive common marmosets to its cffects in groups of animals exposed to MPTP either 2 months or 10 months prior to the administration of terguride. The results obtained under these conditions are discussed in view of the pharmacological effects of terguride in paticnts.

\section{Materials and methods}

\subsection{Animals}

Common marmosets (Callithrix jacchus) of either sex weighing $280-420 \mathrm{~g}$ and aged $6-10$ years at the beginning of the study were used. The animals were housed in pairs or alone under standard conditions at a temperature of $27^{\circ} \mathrm{C}\left( \pm 1^{\circ} \mathrm{C}\right)$ and $50 \%$ relative humidity with a 12-h light-dark cycle (light on from 6:00 to 18:(0) h). The animals had free access to food pellets (Mazuri primate diet) and tap water, and in addition received a daily ration of fresh fruit and Mazuri marmoset jelly. During MPTP treatment and throughout the following weeks the animals were hand-fed with Mazuri marmoset jelly and fresh fruit puree until they were able to maintain themselves. Electrolyte, nutrient and fluid balance were maintained by s.c. infusion of an elcctrolyte, amino acid and vitamin solution (Duphalyte, Duphar, UK) when necessary.

\subsection{Measurement of locomotor actility}

Locomotor activity was measured simultaneously in four aluminium cages $(50 \times 60 \times 70 \mathrm{~cm})$ with stainless steel grid doors $(50 \times 70 \mathrm{~cm})$ identical to the animals' home cages but equipped with eight horizontally orientated sets of infrared photocells. Across the cage three beams were located at floor level and one along each of the two perches. Other beams were directed from front-to-back of the cage at floor level and above each perch. The number of light beam interruptions due to the animal's movements were accumulated in $10-\mathrm{min}$ intervals and recorded for $360 \mathrm{~min}$, using a Commodore CBM 4032 computer. The animals were allowed to acclimatize to the test cage for a minimum of $30 \mathrm{~min}$ prior to drug treatment.

\subsection{Behavioural obseriations}

In parallel to the automated recording of locomotor activity the animals were observed under blinded conditions through a one-way mirror. Motor behaviour was rated qualitatively to determine the presence or absence of stereotypy, head twitches, wet-dog shakes or grooming, oral movements, co-ordination of movement (good/impaired) and other obvious motor signs in 5min intervals for $360 \mathrm{~min}$ after drug administration. The maximal score for each item was 72 .

\subsection{Drugs and solutions}

The following compounds were used: MPTP (1methyl-4-phenyl-1,2,3,6-tetrahydropyridine hydrochloride; Schering $A(G)$ and terguride (Schering AG). MPTP was dissolved in sterile physiological saline and terguride was suspended in sterile physiological saline containing $100 \mathrm{~g} / 1$ polycthoxylated castor oil (Cremophor EL, BASF, FRG). All solutions were prepared immediately before administration.

\subsection{MPTP treatment}

The animals were treated with MPTP in doses of 2 $\mathrm{mg} / \mathrm{kg}$ s.c. daily for up to 6 days. Since the response of individual animals differed markedly, variable dose regimes were applied to obtain comparable initial motor deficits. Impairment of motor function was quantified daily with a rating scale (Löschmann et al., 1989). The animals were treated until they reached a maximal disability score of $1824 \mathrm{~h}$ after the last MPTP injection. The cumulative doses administered ranged from 8 to $12 \mathrm{mg} / \mathrm{kg}$. After MPTP treatment the animals recovered from acute effects over a pcriod of some weeks. During the following months a further gradual recovery from the MPTP effects was observed. One group of three animals was tested 2 months (group A) 
and a second group of three animals 10 months (group B) after exposure to MPTP.

\subsection{Drug treatments}

A group of four marmosets was treated with vehicle and one of the three doses of terguride $(4.0,8.0$ or 12.0 $\mathrm{mg} / \mathrm{kg}$ i.p.) over the following weeks, allowing 1 week recovery between experiments. Treatments were randomized within the group. MPIP-treated marmosets were tested either 2 months (group $\mathrm{A}, \mathrm{N}=3$ ) or 10 months (group $B, N=3$ ) after MPTP treatment with vehicle or one of the three doses of terguride (4.0, 8.0 or $12.0 \mathrm{mg} / \mathrm{kg}$ i.p.) in a identical design. All experiments started at 11:00 a.m. and finished at 5:00 p.m.

\subsection{Data analysis}

The means \pm S.E.M. were calculated for time courses and accumulated locomotor counts of the different treatment groups. Statistical differences were calculated for accumulated locomotor counts by the non-parametric Page test for non-independent data. Intraindividual monotonc trends of treatment effects were detected using the ordered alternative: vehicle < $4.0<8.0<12 \mathrm{mg} / \mathrm{kg}$, using exact distributions followed by sequential tests against two alternative hypotheses (vehiclc $<4.0<8.0 \mathrm{mg} / \mathrm{kg}$ ) or (vehicle $<4.0$ and $8.0<12.0 \mathrm{mg} / \mathrm{kg}$ ) when appropriate.

\section{Results}

When adapted to the environment of the test cages, naive common marmosets showed very little locomotor activity when not disturbed. Injection of vehicle was followed by a 30 -min period of exploratory activity but,

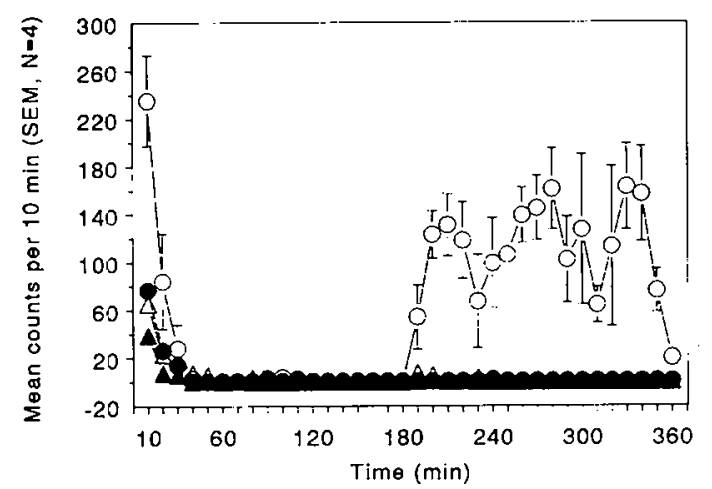

Fig. 1. Mean locomotor activity counts $(+$ S.F.M. $N-4)$ accumulaled in 10-min intervals for $180 \mathrm{~min}$ of naive common marmosets treated with vehicle $(C)$ or $4.0(\bullet), 8.0(\Delta)$ and $12.0(\Delta) \mathrm{mg} / \mathrm{kg}$ of te: guride, respectively. Error bars for the treatment groups are omitted for clarity but were within the same range as those shown for the vehicle group.
TABLE 1

Median stereotypy scores with the range in parentheses over $360 \mathrm{~min}$ after treatment of common marmosets with terguride.

\begin{tabular}{llcl}
\hline Treatment & Normal & $\begin{array}{l}2 \text { months } \\
\text { post MPTP }\end{array}$ & $\begin{array}{l}10 \text { months } \\
\text { post MPTP }\end{array}$ \\
\hline Vehicle & $0(0)$ & $0(0)$ & $0(0)$ \\
$4 \mathrm{mg} / \mathrm{kg}$ & $0(0)$ & $4(5)$ & $3(3)$ \\
$8 \mathrm{mg} / \mathrm{kg}$ & $0(0)$ & $7(5)$ & $2(3)$ \\
$12 \mathrm{mg} / \mathrm{kg}$ & $0(0)$ & $21(14)$ & $4(1)$ \\
\hline
\end{tabular}

thereafter, little or no activity for up to $180 \mathrm{~min}$. This exploratory activity was dose dependently reduced by terguride $4.0,8.0$ and $12.0 \mathrm{mg} / \mathrm{kg}$ i.p. (figs. 1 and 4 ). At later times vehicle-treated animals were more active whereas terguride-treated animals showed almost complete akinesia.

Prior to behavioural testing, all animals of group A (treatment with MPTP 2 months before the experiment) showed a reduction in basal locomotor activity and exhibited slower and less coordinated movements, reduced checking movements of the head and eyeblinks as well as abnormal posturcs of some parts of the body. The behavioural deficits were different in group B (treatment with MPTP 10 months before testing). Locomotor activity was still reduccd in one of these animals whercas another showed signs of hyperexcitability and unrest. The behaviour of the third animal was not different from that of controls.

Animals treated with MPTP 2 months prior to the experiment (group A) showed reduced locomotor activity when exposed to vehicle. Terguride stimulated locomotor activity in the first $180 \mathrm{~min}$ after administration. Because stereotyped movements were elicited by the higher doses tested, $4.0 \mathrm{mg} / \mathrm{kg}$ of terguride was most effective (fig. 4 and table 1 ). The stimulatory effect of terguride was more pronounced during the last $3 \mathrm{~h}$ of

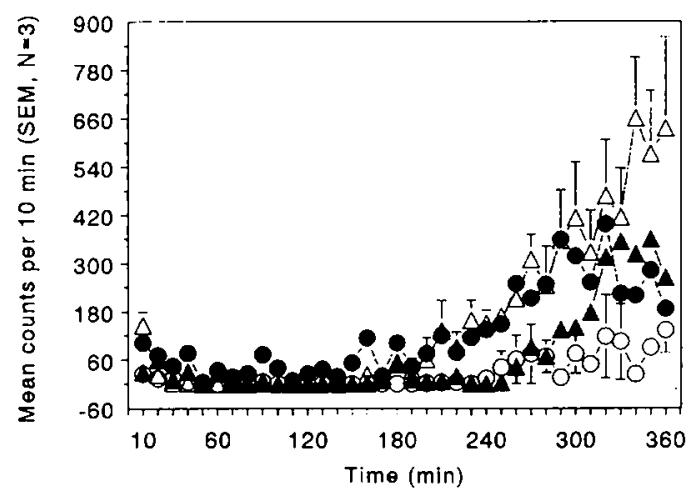

Fig. 2. Mean locomotor activity counts (i. S.E.M., $N=3$ ) accumulated in 10-min intervals for 360 min of common marmosets pretreated with MP'IP 2 months prior to the administration of vehicle $(0)$ or $4.0(\bullet), 8.0(\Delta)$ and $12.0(\Delta) \mathrm{mg} / \mathrm{kg}$ of terguride, respectively. Error bars for the higher doses are omitted for clarity but were within the same range as those shown for $8.0 \mathrm{mg} / \mathrm{kg}$ or vehicle i.p. (note the difference in scale to fig. 1). 


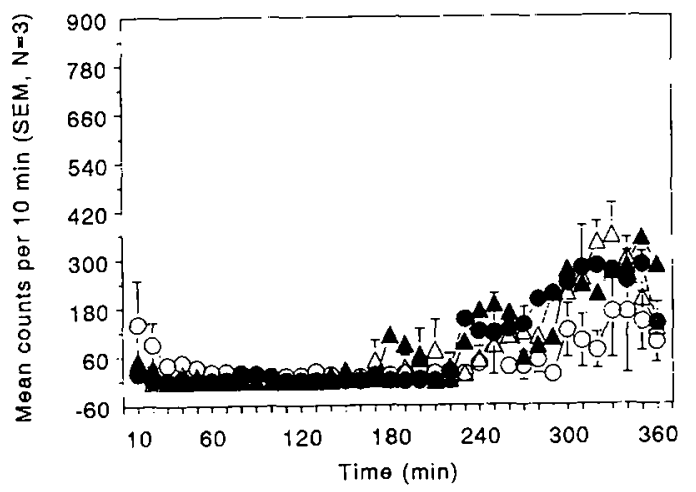

Fig. 3. Mean locomotor activity counts (+ S.E.M., N. 3) accumulated in 10 -min intervals for $360 \mathrm{~min}$ of common marmosets pretreated with MPTP 10 months prior to the administration of vehicle $(0)$ or $4.0(\bullet), 8.0(\Delta)$ and $12.0(\Delta) \mathrm{mg} / \mathrm{kg}$ of terguride, respectively. Error bars for the higher doses are omitted for clarity but were within the same range as those shown for $8.0 \mathrm{mg} / \mathrm{kg}$ or vehicle i.p.

the observation period (fig. 2). Vehicle-treated animals showed some activity at this time of day, when they are usually fed. Marmosets treated with 4.0 and $8.0 \mathrm{mg} / \mathrm{kg}$ of terguride were cleariy stimulated. The presence of stereotypies (table 1) resulted in a smaller stimulation of locomotion after administration of $12 \mathrm{mg} / \mathrm{kg}$ of terguride i.p. (fig. 5).

The basal locomotor activity of common marmosets treated with MPTP 10 months prior to the experiment (group B) was variable, leading to somewhat higher activity counts after vehicle treatment as compared with controls and animals of group A (figs. 3 and 4). Treatment with terguride reduced locomotor activity at

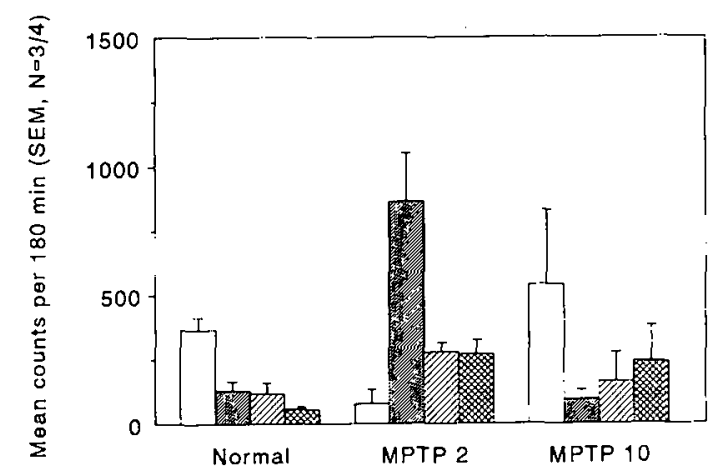

Fig. 4. Mcan locomotor activity counts ( $\rightarrow$ S.F.M.) accumulated over 180 in for the data shown in figs. 1-3. All groups of common marmosets were treated with vehicle (open columns), 4.0 (dense hatched columns), 8.0 (hatched columns) and 12.0 (crossed columns) $\mathrm{mg} / \mathrm{kg}$ of terguricte. In naive animals terguride dose dependently reduced locomotor activity $(\mathrm{P}<0.01$, Page test, ordered alternative: vehicle $>4.0>8.0>12.0 \mathrm{mg} / \mathrm{kg}$ of terguride). In common marmosets treated with MPTP 2 months prior to the experiment, terguride stimulated locomotor activity at the lowest dose tested (4.0 $\mathrm{mg} / \mathrm{kg}$ i.p., $\mathrm{P}<0.05$, Page test; ordered alternative: vehicle $<4.0$ and $8.0<12.0 \mathrm{mg} / \mathrm{kg}$ of terguride). In animals exposed to MPTP 10) months prior to the experiment, terguride reduced locomotor activity up the highest dose tested although the effect was not significant.

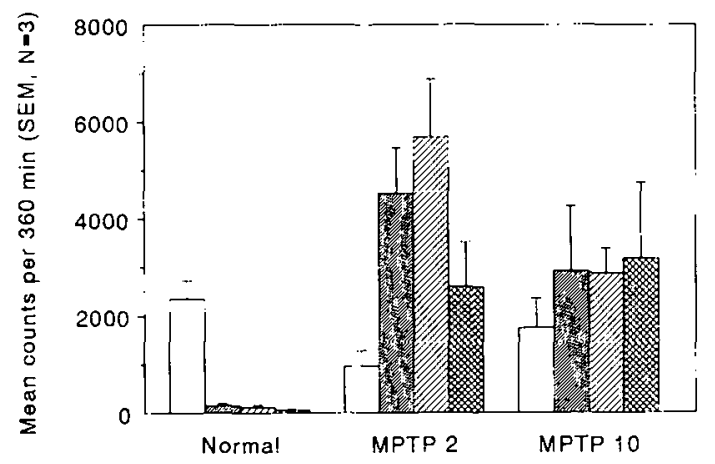

Fig. 5. Mean locomotor activity counts ( \pm S.E.M., $N=3$ ) accumulated over $360 \mathrm{~min}$ for the data shown in figs. 2 and 3 . Both groups of common marmosets were treated with vehicle (open columns), 4.0 (dense hatched columns), 8.0 (hatched columns) and 12.0 (crossed columns) $\mathrm{mg} / \mathrm{kg}$ of tcrguride. In animals treated with MPTP 2 months prior to the experiment, terguride cicarly stimulated locomotor activity at the lower doses tested $(4.0$ and $8.0 \mathrm{mg} / \mathrm{kg}$ i.p.). Iowever, due to the variability of individual animal responses, this effect was not statistically significant. In common marmosets exposed to MPTP 10 months prior to the experiment, terguride had no effect upon locomotor activity.

all doses tested, although the effect did not seem to be dose-dependent. During the second 3-h period, terguride showed a tendency to stimulate locomotor activity. Again, this effect was not significant (figs. 3 and 5) for the 6-h observation period. None of the doses of terguride tested induced pronounced stercotyped movements in this group of animals (table 1).

\section{Discussion}

In rodents without lesions, terguride has DA antagonistic properties, resulting in a reduction of locomotor activity and in catalepsy when higher doses are administered. In line with these findings, the compound reduces exploratory locomotor activity of normal common marmosets. This depressant effect lasts up to $6 \mathrm{~h}$. DA agonistic properties are unmasked in rodents pretreated subchronically with reserpine (Wachtel et al., 1984). It is likcly that the depletion of monoaminergic tcrminals may lead to an increased sensitivity of postsynaptic receptors. The anti-parkinsonian activity of terguride in the MPTP-treated primate, the most reliabie model for Parkinson's disease at present available, has been shown previously. The compound induces rotations in monkeys rendered hemiparkinsonian by intracarotid infusion of MPTP (Brücke et al., 1988). In accord with these findings, our data indicate that DA agonistic effects in the MPTP-treated common marmoset are also critically dependent on the receptor status. A clear stimulatory effect was only seen in animais treated 2 months prcviously with MPTP when they had not recovered behaviourally from the MPTP treatment. In the first $3 \mathrm{~h}, 4 \mathrm{mg} / \mathrm{kg}$ of terguride 
produced the greatest response (fig. 4) whereas in the 6-h period 4 and $8 \mathrm{mg} / \mathrm{kg}$ stimulated locomotor activily (fig. 5). In animals that had recovered from MPTP treatment given 10 months previously, terguride inhibi.ed locomotor activity in the first $3 \mathrm{~h}$, as it did in rormal marmosets, although this effect was not statistically significant. However, in the 6-h period, all doses tested slightly stimulated locomotor activity, a response consistent with the weak DA agonistic effects of terguride under these conditions. We hypothesize that the bchavioural recovery of common marmosets is accompanied by a normalization of receptor sensitivity duc to changes in either the binding affinity or the coupling of receptors to second messenger systems. Thus, in animals recovered from prior MPTP treatment, the increased DA turnover (Rose et al., 1989) could lead to a higher availability of DA and subsequent normalization of the sensitivity of presynaptic autoreceptors. Under these conditions terguride would act as autoreceptor agonist, resulting in a reduced DA release and inhibition of locomotor activity during the initial 3-h period. In the second 3-h period, terguride would exert weak DA agonistic properties at postsynaptic receptors.

An alternative explanation involves the partial DA agonistic properties of terguride. Thus, the increased DA turnover could lead to a higher availability of DA, with terguride antagonizing the effects of endogenous DA. The initial inhibition of locomotor activity could be explained by such a phenomenon. Since terguride did not reduce but slightly increased locomotor activity in recovered common marmosets over the 6-h period, the latter hypothesis seems less likely.

Two facets of the effects of terguride are of interest when compared with the effects of direct DA agonists such as (+)-PHNO (Nomoto et al., 1987) in this animal rodel. First, terguride did not cause a rapid and sustained locomotor hyperactivity even with the relatively high doses used. Second, the normal diurnal pattern of locomotor activity was preserved. Increased activity after treatment with terguride was seen during periods of higher basal locomotor activity under control conditions. Both observations contrast with the stimulatory effect on locomotor activity seen in reserpinized-rodents and are compatible with the idea that terguride 'enables' voluntary locomotion in the MPTP-treated marmoset rather than causes hyperstimulation. This atypical pharmacological profilc, in which DA agonistic and DA antagonistic properties are comtined in one molecule, has been described as mixed DA agonism/antagonism in rodents. Our data show similar effects of terguride in a primate species.

The unique pharmacological profile of terguride suggests an interesting range of possible indications, some of which have alrcady been tested in clinical trials. Like classical DA agonists, single doses of terguride ranging from 0.25 to $1.0 \mathrm{mg}$ lower prolactin levels in humans and produce endocrine effects identical to those seen with bromocriptinc, but with less side effects. In a double-blind cross-over study, subjects could not distinguish the lower terguride doses from placebo and $1 \mathrm{mg}$ of terguride was always preferred to $2.5 \mathrm{mg}$ bromocriptine (Ciccarclli ct al., 1988). Clinical observations confirm that terguride is useful in the treatment of hyperprolactinaemic conditions including prolactinomas (Dallabonzana et al., 1986). Antiparkinsonian effects have been reported when terguride was used as monotherapy or combined with L-Dopa in advanced disease (Corsini et al., 1985). In open clinical trials in paticnts with Parkinson's disease, especially in elderly patients (Brücke et al., 1986), there was a low frequency of typical dopamincrgic side effects such as nausea, cmesis or orthostatic hypotension. However, in a double-blind study in de novo patients terguride was better tolerated but less active than lisuride after 3 months of therapy and its possible long-term effects are still under investigation (U.K. Rinne, personal communication). In placebo-controlled double-blind studies in patients with motor fluctuations, terguride added to L-Dopa had a significant effect on disability and also improved wearing off and dyskinesias ( $\mathrm{E}$. Martignoni and G. Nappi, personal communication). In these studics antidyskinetic and anti-akinetic effects of terguride were observed in the same patients. Terguride had very pronounced anti-dyskinetic effects without interference with the anti-akinetic effects of L-Dopa in parkinsonian patients with motor fluctuations as shown in a double-blind placebo-controlled study (Baronti et al., 1989 and submitted for publication). Terguride has positive effects on tardive dyskinesia even in the presence of neuroleptic drugs (Säkö ct al., 1987). Finally, in an open clinical trial, including 11 patients with chronic schizophrenia and marked negative symptoms, terguride improved symptomatology in cight patients on the scalc for assessment of negative symptoms (SANS). In none of the patients were psychotic symptoms elicited and the compound was well tolerated (Olbrich and Schanz, 1988).

Mixed DA agonist /antagonists may have good antiparkinsonian actions with fewer side effects, especially in patients susceptible to motor fluctuations, dyskinesias, psychosis or enhanced sensitivity towards dopaminergic drugs.

In conclusion, the MPTP-treated common marmoset offers a uscful pharmacological model and is of predictive value for the characterization of not only classical direct DA agonists but also mixed DA agonist/antagonists. Terguride can be used in a pharmacological in vivo test for the assessment of the sensitivity status of central DA receptors in MPTP-treated primates. Terguride could also be valuable for the assessment of the function of dopaminergic cell transplants. 


\section{Acknowledgements}

K.W. Lange was supported by the Furopean Science Foundation and the Furopean Medical Rescarch Council. P.A. Löschmann was a visiting research fellow at the University Department of Clinical Neurology, Institute of Neurology, The National Hospital, Queen Square, London.

\section{References}

Baronti, F., M.M. Mouradim. S. Brughitta, K.E. Conant, M. Giaffra and T.N. Chase, 1989. Partial dopamine agonist therapy of levodopa-induced dyskinesia, Neurology 39, 556.

Brücke, T., W. Danielczyk, M. Simányi, F. Sofic and P. Riederer, 1986, Terguride: partial dopamine agonist in the treatment of Parkinson's disease, in: Advances in Neurology, Vol. 45, eds. M.D. Yahr and K.J. Bergmann (Raven Press. Ncw York) p. 573.

Brücke, T., K. Bankicwicz, J. Harvey-White and I. Kopin, 1988, The partial dopamine agonist terguride in the MPTP-induced hemiparkinsonian monkey model, Eur. J. Pharmacol. 148, 445.

Burns, R.S., C.C. Chiuch, S.P. Markey, M.H. Ebert, D.M. Jacobowitz and I.J. Kopin, 1983, A primate model of parkinsonism: selective destruction of dopaminergic neurons in the pars compacta of the substantia nigra by $\mathrm{N}$-methyl-4-pheny!-1,2,3,6-tetrahydropyridinc, Proc. Natl. Acad. Sci. [I.S.A. 80, 4546.

Ciccarelli, E., R. Touzel, M. Besser and A. Cirossman, 1988, Terguride - a new dopamine agonist drug: a comparison of its neuroendocrine and side effect profile with bromocriptine, Fertil. Steril. 49, 589.

Corsini, G.U.. U. Bonuccelli, L. Rainer and M. Del 7ompo. 1985, Therapeutic efficacy of a partial dopamine agonist in drug-free parkinsonian patients, J. Neural Transm. 64, 105.

Dallabonzana, D., A. Liuzzi, G. Oppizzi, R. Cozzi, G. Verde, P. Chiodini, E. Rainer. R. Dorow and R. Iorowski, 1986. Chronic treatment of pathological hyperprolactinemia and acromegaly with the new crgot derivative terguride. J. Clin. Lndocrinol. Metab. 63, 1002.

Davis, G.C., A.C. Williams, S.P. Markey, M.H. Ebert, k.I). Caine, C.M. Reichert and I.J. Kopin, 1979, Chronic parkinsonism secondary to intravenous injections of meperidine analogues, Psychiat. Res. 1, 249.

Dlabač. A. and I. Krejčí, 1980, Central dopaminergic effects of ergoline derivatives, Activ. Nerv. Sup. (Praha) 22, 208.

Jenner, P., N.M.J. Rupniak, S. Rose, E. Kelley, G. Kilpatrick, A. Lees and C.D. Marsden 1984, 1-Methyl-4-phenyl-1,2,3,6-tetrahydropyridine-induced parkinsonism in the common marmoset, Nicurosci. Lett. $50,85$.

I angston, J.W., P. Ballard, J.W. Tetrud and I. Irwin, 1983, Chronic parkinsonism in humans due to a product of meperidine-analng synthesis, Science 225,1480 .
Löschmann, P.-A., P.V. Chong, M. Nomoto, P.G. Tepper, A.S. Iorn, P. Jenner and C.D. Marsden, 1989, Stereoselective reversal of MPIP-induced parkinsonism in the marmoset after dermal application of N-0437, Fur. J. Pharmacol. 166, 373.

Löschamnn, P.-A., K.J. Kettig, R. Horowski, H. Wachtel, K.W. I ange, P. Jenner and C.D. Marsden, 199la, Terguride, a dopamine partial agonist for the treatment of Parkinson's discase, in: Basic, Clinical, and Therapcutic Aspects of Alzheimer's and Parkinson's Diseases, Vol. 2, eds. T. Nagatsu, $\Lambda$. Fisher and M. Yoshida (Pienum Publishing Corporation, New York) p. 569.

Iöschmann, P.-A., K.J. Retlig, H. Wachtel, R. Dorow, P. Jenner and C.D. Marsden, 1991b, lisuride and proterguride reverse MPTPinduced parkinsonism in the common marmoset, in: Basic, Clinical. and Therapeutic Aspects of Alzheimer's and Parkinson's Diseases, Vol. 2, eds. T. Nagatsu, A. Fisher and M. Yoshida (Plenum Publishing Corporation, New York) p. 565.

Marsden, C.I. and J.D. Parkes, 1976, 'On-off' effects in patients with Parkinson's disease on chronic lcvodopa therapy, Lancet 1, 292.

Nomoto, M., S. Stahl, P. Jenner and (.D. Marsden, 1987, Antiparkinsonian activity of (+)-PINO in the MPTP treated common marmoset, Movement Disorders 2, 37.

Olbrich, R. and II. Schanz, 1988, The effect of the partial dopamine agonist terguride on negative symptoms in schizophrenics, Pharmacopsychiatry 21, 389 .

Rose, S., M. Nomoto, L. Kelly, G. Kilpatrick, P. Jenner and C.D. Marsden, 1989. Increased caudate dopamine turnover may contribute to the recovery of motor function in marmosets treated with the dopaminergic neurotoxin MPTP, Neurosci. I.ett. 101, 305.

Säkö, E., R. Jokinen, V. Räkköläinen, L.K. Rinne and I. Suchy, 1987. The effect of terguride in tardive dyskinesia. Acta Neurol. Scand. 77 (Suppl.). 93.

Ueki, A.. P.N. Chong, A. Abanese, S. Rose, J.K. Chivers, P. Jenner and C.D. Marsden. 1989, Further treatment with MPTP does not produce parkinsonism in marmosets showing behavioural recovery from motor deficits induced by an earlier exposure to the toxin. Neuropharmacology $28,1089$.

Valchár, M., M. Vrsecká, I. Krejčí and A. Dlabač, 1987, Binding characteristics of the dopamine agonist/antagonist $\left[{ }^{3} \mathrm{H}\right] \mathrm{terguride}$ (transdihydrolisuride) in the rat striatum, Fur. J. Pharmacel. 136, 97.

Wachtel, YI. and R. Dorow, 1983, Dual action on central dopamine function of transdihydrolisuride. a 9,10-dihydrogenated analogue of the ergot dopamine agonist lisuride, Life Sci. 32, 421.

Wachtel, H.. K.-J. Rettig and $\Lambda$. Selty, 1984, The central dopamine agonistic action of transdihydrolisuride is unmasked at supersensitive receptors, Naunyn-Schmiedeb. Arch. Pharmacol. 325 (Suppi) 80. 